\title{
PENGARUH KOMPETENSI PEDAGOGIK TERHADAP MINAT BELAJAR SISWA
}

\author{
Devita Meli \\ Mahasiswi MPI FITK IAIN Sultan Amai Gorontalo \\ Arten H. Mobonggi \\ Institut Agama Islam Negeri Sultan Amai Gorontalo \\ Alfian Erwinsyah \\ Institut Agama Islam Negeri Sultan Amai Gorontalo
}

\begin{abstract}
Abstrak
Penelitian ini merupakan penelitian kuantitatif dengan tujuan untuk mengetahui apakah ada pengaruh dan seberapa besar pengaruh kompetensi pedagogik guru terhadap minat belajar. Penelitian ini dilaksanakan di SMP Negeri 11 Gorontalo. Adapun dalam pengumpulan data, peneliti menggunakan angket (kuesioner). Angket tersebut berjumlah 27 item pernyataan yang sudah peneliti lakukan uji coba sebelumya. Pernyataan atau angket tersebut di sebarkan kepada sampel penelitian yang berjumlah 32 untuk variabel $X$ dan 80 untuk variabel $Y$ orang responden.

Hasil Penelitian menunjukkan terdapat pengaruh positif kompetensi pedagogik guru terhadap minat belajar siswa dengan persamaan regresi $Y=20.450+0.710 x . d i$ mana signifikanya berpengaruh tersebut ditunjukan oleh nilai $t_{\text {hitung }}$ (uji t) di mana $t_{\text {hitung }}$ $>t_{\text {tabel }}$ yaitu $3.959>0.361$ dengan nilai signifikansi $<0.05$ yaitu 0.000 dengan sumbangan relatif sebesar 100\% dan sumbangan efektif 34.3\%. Melalui analisis regresi sederhana pada tabel $R$ Square, diketahui Pengaruh variabel $X$ (Kompetensi pedagogik guru) terhadap variabel Y (minat belajar siswa) di SMP Negeri 11 Gorontalo sebesar $34.3 \%$, hal ini berarti $65.7 \%$ minat belajar siswa dipengaruhi oleh faktor yang lain.

Setelah diketahui bahwa terdapat pengaruh antara variabel $X$ (kompetensi pedagogik guru) dan variabel Y (minat belajar siswa) di SMP Negeri 11 Gorontalo sebesar .34.3\%. Maka nilai koefisien korelasi tersebut, dapat menjadi acuan yang sangat kuat untuk mengajukan penelitian ini dalam pengujian regresi sederhana untuk mendapatkan nilai konstanta variabel $Y$ (minat belajar siswa) dan sekaligus mendapatkan nilai persamaan regresi yang bertujuan untuk meramalkan perubahan nilai variabel Y (minat belajar siswa) di SMP Negeri 11 Gorontalo yang disebabkan oleh variabel $X$ (kompetensi pedagogik guru).
\end{abstract}

Kata Kunci: Kompetensi Pedagogik, Minat Belajar

\section{PENDAHULUAN}

Dalam dunia pendidikan, keberadaan peran dan fungsi guru merupakan salah satu faktor yang sangat signifikan. Guru merupakan bagian terpenting dalam proses belajar mengajar, baik di jalur pendidikan formal maupun informal. Oleh sebab itu, dalam setiap 
upaya peningkatan kualitas pendidikan di tanah air, tidak dapat dilepaskan dari berbagai hal yang berkaitan dengan eksistensi guru itu sendiri. ${ }^{1}$

Masalah kompetensi merupakan salah satu faktor penting dalam pembinaan guru sebagai suatu jabatan propesi. ${ }^{2}$ Dalam UU Nomor 14 tahun 2005 tentang Guru dan Dosen ditetapkan bahwa guru wajib memiliki kompetensi pedagogik, kompetensi kepribadian, kompetensi sosial, dan kompetensi profesional yang diperoleh melalui pendidikan profesi. (pasal 10 ayat 1 ). ${ }^{3}$ Kinerja guru pada dasarnya merupakan unjuk kerja yang dilakukan oleh guru dalam melaksanakan tugasnya sebagai pendidik. Kualitas kinerja guru akan sangat menentukan pada kualitas pendidikanm, karena guru merupakan pihak yang paling banyak bersentuhan langsung dengan siswa dalam proses pendidikan/pembelajaran di lembaga pendidikan sekolah. ${ }^{4}$ Guru juga merupakan salah satu komponen dalam sistem pendidikan nasional mempunyai peran utama dalam pencapaian tujuan pendidikan nasional. ${ }^{5}$

Kompetensi adalah seperangkat pengetahuan, keterampilan, dan perilaku yang harus dimiliki, dihayati, dan dikuasai oleh guru dalam melaksanakan tugasnya. Kompetensi bermakna kewengan atau kekuasaan untuk menentukan atau memutuskan sesuatu. Maksudnya bahwa, seseorang yang memiliki kompetensi berarti memiliki kewenangan dan tanggung jawab terhadap tugas yang diembanya, guru yang berkompetensi harus tetap menjaga eksistensinya dan menjaga wibawanya di hadapan siswa.

Menurut Siti Suwadah Rimang, kompetensi pedagogik adalah kemampuan seorang guru dalam mentransfer ilmu yang dimiliki guru kepada anak didiknya. Sudarman Danim, menggungkapkan kompetensi pedagogik adalah kemampuan guru yang meliputi kemempuan memahami peserta didik secara mendalam, merancang pembelajaran, melaksanakan pembelajaran, merancang dan melaksanakan evaluasi pembelajaran, dan mengembangkan peserta didik untuk mengaktualisasikan berbagai potensinya. Pendapat lain dikemukakan Uyoh Sadulloh, kompetensi pedagogik merupakan ilmu yang membahas tentang pendidikan, yaitu ilmu pendidikan anak yang menjelaskan seluk beluk pendidikan anak. ${ }^{6}$

Dengan ditetapkanya jenis kompetensi guru dalam Undang-Undang Guru dan Dosen, maka atas dasar penetapan itu akan dapat diobservasi dan ditentukan guru yang telah memiliki kompetensi penuh dan guru yang masih kurang memadai kompetensinya. Informsi tentang hal ini sangat sangat diperlukan oleh para administrator dalam usaha

\footnotetext{
${ }^{1}$ Daryanto, Guru Profesional,(Yogyakarta: Gava Media, 2013), h. 1.

${ }^{2}$ Rahman Getteng, Menuju Guru Profesional dan ber-etika,( Cet. VI, Yogjakarta: Grha Guru,2011), h. 29

${ }^{3}$ Undang-Undang Republik Indonesia Nomor 20 Tahun 2003 Tentang SISDIKNAS, (Bandung:Fermana, 2006),h. 4

${ }^{4}$ Erwinsyah, Alfian. "Penerapan Pembelajaran Berbasis Teknologi Informasi Dalam Menunjang Kinerja Guru." In Prosiding Seminar Nasional Administrasi Pendidikan \& Manajemen Pendidikan, pp. 185-192. 2018.

${ }^{5}$ Sidik, Firman. "Guru Berkualitas Untuk Sumber Daya Manusia Berkualitas." Tadbir: Jurnal Manajemen Pendidikan Islam 4.2 (2016): 109-114.

${ }^{6}$ Ahmad Rasuli,Wanto Rivaie,Sulistyarini”, kompetensi guru dalam meningkatkan hasil belajar siswa mata pelajaran sosiologi" https://www.jurnal.untan.ac.id/ ,diakses pada hari sabtu 29-09-2018
} 
pembinaan dan dan pengembanagan terhadap para guru sebagai upaya untuk meningkatkan kualitas pendidikan sesuai amanat Undang-Undang Negara RI Nomor 20 Tahun 2003 Tentang Sistem Pendidikan Nasional. ${ }^{7}$

Pedagogik merupakan ilmu yang mengkaji bagaimana membimbing anak, bagaimana sebaiknya pendidik berhadapan dengan anak didik, apa tugas pendidik dalam mendidik anak,apa yang menjadi tujuan mendidik anak. Dalam bagian ini pedagogik dalam arti khusus dan dalam arti luas. Pendidikan mengandung tiga aspek yaitu mendidik, mengajrdan melatih. ${ }^{8}$

Minat belajar siswa dalam mengikuti pembelajaran merupakan sesuatu yang penting dalam kelancaran proses belajar mengajar. Siswa yang mempunyai minat belajar tinggi dalam proses pembelajaran dapat menunjang proses belajar mengajar untuk semakin baik, begitupun sebaliknya minat belajar siswa yang rendah maka kualitas pembelajaran akan menurun dan akan berpengaruh pada hasil belajar. Slameto menerangkan minat adalah "Kecenderungan hati yang tinggi terhadap sesuatu". Minat merupakan sifat yang relatif menetap pada diri seseorang. Minat adalah ketertarikan atau kecenderungan yang tetap untuk memperhatikan atau terlibat terhadap sesuatu hal karena menyadari pentingnya atau bernilainya hal tersebut. ${ }^{9}$

Berdasarkan hasil observasi awal peneliti di SMP Negeri 11 Kota Gorontalo, ditemukan beberapa permasalahan mengenai hal tersebut, yaitu disebabkan karena belum maksimalnya kompetensi pedagogik guru dalam memahami peserta didik di dalam kelas, guru sulit menyesuaikan model pembelajaran yang dipakai dengan tingkah laku peserta didik dalam merancang, melaksanakan pembelajaran. Guru tersebut masih menggunakan metode-metode itu saja, dan juga guru tersebut tidak bisa mengembangkan potensi yang dimiliki oleh setiap siswa, yang sudah seharusnya menjadi tugas dari seorang guru. Hal tersebutlah yang kemudian dirasa kurang, sehingga berdampak pada minat belajar siswa, dimana ketertarikan dan perhatian dalam belajar kurang. Dan juga siswa selalu keluar masuk kelas saat proses pembelajaran karena tidak tertarik dengan model pembelajaran didalam kelas, siswa sering lupa dalam menyelesaikan tugas sekolah karena, tidak perhatian di dalam kelas. Dari hal tersebutlah yang bisa berpengaruh terhadap minat belajar siswa dan berdampak pula pada hasil belajar siswa.

Berdasarkan permasalahan-permasalahan diatas peneliti berasumsi bahwa di mana minat belajar siswa di sekolah ini sangatlah kurang (minim) di mana kebanyakan siswa yang keluar kelas saat proses belajar mengajar sedang berlangsung, dikarenakan guru yang mengajar didalam kelas kurang memahami karakteristik siswa

di dalam kelas dan keterbatasan guru dalam mengelola pembelajaran yang dapat menarik minat belajar siswa. ${ }^{10}$

\footnotetext{
${ }^{7}$ Rahman Getteng, Menuju Guru Profesional dan ber-etika,( Cet. VI, Yogjakarta: Grha Guru,2011), h. 29,31

${ }^{8}$ Imas kurnianigsih dan berlin sani, kupas tuntas kopetensi pedagogik teori dan praktik,(kata pena; 2017),h.73.

${ }^{9}$ Sadulloh uyoh, pedagogik, ilmu mendidik (bandung : alfabet. Rosda karya 2001).

${ }^{10}$ Lukmanul hakiim, perencanaan pembelajaran, (bandung:cv wacana prima 2012), $\mathrm{h}$ 37.38
} 
Berdasarkan latar belakang masalah yang telah diuraikan, maka dapat di identifikasi beberapa permasalahan (1) Apakah kompetensi pedagogik guru berpengaruh secara signifikan terhadap minat belajar siswa di SMP Negeri 11 Kota Gorontalo? (2) Seberapa besar pengaruh kompetensi pedagogik terhadap minat belajar siswa di SMP Negeri 11 Kota Gorontalo

\section{KOMPETENSI PEDAGOGIK}

Undang-undang guru dan dosen No. 14/2005 pasal 10 ayat 1 dan PP No. 19/2005 pasal 28 ayat 3 guru wajib memiliki kompetensi yang meliputi kompetensi pedagogik, kepribadian, sosial, dan profesional. ${ }^{11}$ Sesuai dengan Undang-undang RI no. 14 tahun 2005 tentang guru dan dosen pasal 10 ayat 1,di jelaskan bahwa yang dimaksud dengan kompetensi pedagogik adalah kemampuan mengelola pembelajaran peserta didik. ${ }^{12}$ Kompetensi pedagogik yaitu kemampuan guru dalam mengelola pembelajran yang meliputi,pemahaman terhadap peserta didik, perancangan dan pelaksanaan pembelajaran,evaluasi pembelajaran, dan pengembangan peserta didik untuk mengaktualisasikan berbagai potensi yang dimilikinya. ${ }^{13}$

Kompetensi secara bahasa diartikan sebagai kecakapan dan kemampuan. Dalam kamus bahasa Indonesia, kompetensi diartikan kewenangan, untuk memutuskan atau bertindak. Secara istilah kompetensi mencakup beragam aspek, tidak saja terkait dengan fisik dan mental, tetapi juga aspek spiritual, hal tersebut dikarenakan, kompetensi guru merupakan perpaduan antara kemampuan personal,keilmuan, teknologi, sosial, dan spiritual yang secara kafah membentuk kompetensi standar profesi guru, yang mencakup penguasaan materi, pemahaman terhadap peserta didik, pembelajaran yang mendidik, pengembangan pribadi dan profesionalisme".

Johnson dalam memaknai kompetensi sebagai perilaku rasional guna mencapai tujuan yang dipersyaratkan sesuai dengan kondisi yang diharapkan. Sementara Broke and Stone mengatakan bahwa kompetensi merupakan gambaran hakikat kualitatif dari perilaku guru yang tampak sangat berarti. Sedangkan menurut Undang-Undang No.14 Tahun 2005 tentang Guru dan Dosen pasal 1, ayat10, disebutkan "kompetensi adalah seperangkat pengetahuan, keterampilan, dan perilaku yang harus dimiliki, dihayati dan dikuasai oleh guru atau dosen dalam melaksanakan tugas keprofesionalannya. ${ }^{14}$

Kompetensi pedagogik merupakan kemampuan guru dalam mengelola pembelajaran. Untuk memperoleh pembelajaran efektif dan efisien serta mencapai hasil yang diharapkan perlu dilakukan kegiatan manajemen. Guru diharapkan dapat membimbing dan mengarahkan pengembangan kurikulum dan pembelajaran secara efektif serta melakukan pengawasan dalam pengawasan pelaksanaanya.

11 Jamil Suprihatinigrum, Guru Profesional:pedoman Kinerja, Kualifikasi Dan Kompetensi Guru, (jogjakarta: Ar-Ruzz media,2013), h. 100.

12 Zainal Aqib, Menjadi Guru Profesional Berstandar Nasional. (Bandung: Yarma Widya,2009),h.24. 2012),h.27.

${ }^{13}$ Arif Firdausi, Barnaw I, Profil Guru SMK Profesinal , (jogjakarta : ar-ruzz, media

${ }^{14}$ Fitri Indriani, Kompetensi Pedagogik Guru Dalam Mengelola Pembelajaran Ipa Di Sd Dan Mi, jurnal fenomena, 1:7,(yogjakarta,2015),h.19, diakses 29-09-2018 
Untuk mengungkapkan kemampuan guru bersertifikasi pedagogik dapat dilihat dari kemempuan merencanakan pembelajaran dan kemempuan melaksanakan pembelajaran pada siswa. Kemampuan merencanakan pembelajaran dilihat dari beberapa indikator, yaitu : (1). Perumusan tujuan pembelajaran; (2). Pemilihan dan pengorganisasian materi ajar; (3). Pemilihan sumber belajar/ media pembelajaran; (4). Metode pembelajaran; (5). Rancangan penilaian yang sesuai dengan tujuan pembelajaran; (6). Rancangan penilaian yang sesuai dilengkapi dengan instrumen penilaian. Sedangkan kemampuan melaksanakan pembelajaran dilihat lagi dari beberapa indikator yaitu (1) kegitan pembelajaran; (2) membuka pembelajaran; (3) kegiantan inti pelajaran (4) penutup. $^{15}$

Kompetensi pedagogik harus dimiliki oleh setiap guru, termasuk guru Pendidikan Agama Islam. Hendaknya guru agama islam. Hendaknya guru agama islam itu bertaqwa kepada Allah, berilmu, dan berahlak yang baik. Karena menurut Zakiyah, segala yang ada pada dirinya merupakan unsur pembinaan siswa.

Kompetensi pedagogik mengandung karakteristik-karakteristik yang harus dihayati dan diaplikasikan oleh guru sebagai tenaga profesional. Adapun karakteristik dari kompetensi pedagogik adalah ; pemahaman wawasan atau landasan kependidikan, pemahaman terhadap siswa, perencanaan pembelajaran, pengembangan kurikulum/ silabus,pelaksanaan pembelajaran yang mendidik dan dialogis, pemanfaatan tehnologi pembelajaran, evaluasi hasil belajar, serta pengembangan siswa untuk mengaktualisasikan sebagai potensi yang dimilikinya. ${ }^{16}$

Menurut Siti Suwadah Rimang, kompetensi pedagogik adalah kemampuan seorang guru dalam mentransfer ilmu yang dimiliki guru kepada anak didiknya. Sudarman Danim, menggungkapkan kompetensi pedagogik adalah kemampuan guru yang meliputi kemampuan memahami peserta didik secara mendalam, merancang pembelajaran, melaksanakan pembelajaran, merancang dan melaksanakan evaluasi pembelajaran, dan mengembangkan peserta didik untuk mengaktualisasikan berbagai potensinya. Pendapat lain dikemukakan Uyoh Sadulloh, kompetensi pedagogik merupakan ilmu yang membahas tentang pendidikan, yaitu ilmu pendidikan anak yang menjelaskan seluk beluk pendidikan anak. ${ }^{17}$

a. Kemampuan memahami peserta didik

Pemahaman terhadap peserta didik merupakan salah satu kompetensi pedagogik yang harus dimiliki guru. Setidaknya terdapat 4 hal yang harus dipahami oleh guru dari peserta didiknya, yaitu tingkat kecerdasan, kreatifitas, cacat fisik,dan perkembangan kognitif.

b. Merancang pembelajaran

15 Jamil Suprihatinigrum, Guru Profesional:pedoman Kinerja, Kualifikasi Dan Kompetensi Guru, (jogjakarta: Ar-Ruzz media,2013), h. 115 2015),h.74

${ }^{16}$ Siti Asiah T. Pido, Kinerja Guru Tersertifikasi,(Gorontalo: Sultan Amai Press,

${ }^{17}$ Ahmad Rasuli,Wanto Rivaie,Sulistyarini”,kompetensi guru dalam meningkatkan hasil belajar siswa mata pelajaran sosiologi," (jurnal, prodi pendidikan sosiologi,pendidikan IPS,FKIP Untan Pontianak 2012), h. 3-6 diakses pad a hari sabtu 29-09-2018 
Guru merencanakan sistem pembelajaran yang memanfaatkan sumber daya yang ada. Semua akktifitas pembelajaran dari awal hingga akhir telah dapat direncanakan secara strategis, termasuk antisipasi masalah kemungkinan yang timbul dari skenario yang direncanakan.

c. Melaksanakan pembelajaran

Guru menciptakan situasi belajar bagi anak yang kreatif, aktif, dan menyenangkan. Memberikan ruang yang luasbagi anak untuk dapat mengeksplor potensi dan kemampuanya sehingga dapt dilatih dan dikembangkan. ${ }^{18}$ Melaksanakan proses belajar mengajar berkenaan dengan kemampuan guru dalam aktivitas pembelajaran di kelas. Kemampuan ini antara lain menyangkut penerapan metode pembelajaran yang efektif, penguasaan pengendalian kelas (pengelolaan kelas), penggunaan media pembelajaran khusnya media berbasis tehnologi informasi dan komonikasi (TIK), komonikasi dengan peserta didik, dan cara penilaian hasil pembelajara. Semua itu merupakan persyaratan utama agar berlangsung proses pembelajaran yang rfektif. ${ }^{19}$

d. Merancang dan melaksanakan evaluasi pembelajaran

Guru mampu merancang dan menyelenggarakan penilaian proses dan hasil belajar secara berkesinambungan. Guru melakukan evaluasi atas efektifitas proses dan hasil belajar dan menggunakan informasi hasil belajar dan menggunakan informasi hasil penilaian dan evaluasi untuk merancang program remedial dan pengayaan. Guru mampu menggunakan hasil analisis penilaian dalam proses pembelajaranya. ${ }^{20}$

e. Mengembangkan peserta didik untuk mengaktualisasikan potensinya

Seiring dengan kemajuan tehnologi informasi yang telah demikian pesat, guru tidak hanya lagi bertindak sebagai penyaji informasi tetapi juga harus mampu bertindak sebagai fasilitator, motivator, dan pembimbing yang lebih banyak memberikan kesempatan kepada peserta didik untuk mencari dan mengola sendiri informasi. Dengan demikian keahlian guru harus terus dikembangkan dan tidak hanya terbatas pada penguasaan prinsip mengajar. ${ }^{21}$

\section{MINAT BELAJAR}

Minat belajar dapat diukur melalui 4 indikator sebagaimana yang disebutkan oleh (Slameto) yaitu ketertarikan untuk belajar, perhatian dalam belajar, motivasi belajar dan pengetahuan. Ketertarikan untuk belajar diartikan apabila seseorang yang berminat terhadap suatu pelajaran maka ia akan memiliki perasaan ketertarikan terhadap pelajaran tersebut. Ia akan rajin belajar dan terus memahami semua ilmu yang berhubungan dengan

\footnotetext{
${ }^{18}$ E. Mulyasa, standar kompetensi dan sertifikasi guru (cet. VI: jakarta, remaja rosdakarya,2012),h.79-81

${ }^{19}$ Rulam ahmadi, Profesi keguruan,(jogjakarta,AR RUZZ MEDIA, 2 018),h.23

${ }^{20}$ Imas Kurnanigsih dan berlin sani, kupas tuntas kompetensi pedagoagik teori dan praktek untuk peningkatan kinerja dan kualitas guru,(kata pena,2017),h.51

${ }_{21}$ Imas Kurnanigsih, kupas tuntas kompetensi pedagoagik teori dan praktek untuk peningkatan kinerja dan kualitas guru,(kata pena,2017),h.97
} 
bidang tersebut, ia akan mengikuti pelajaran dengan penuh antusias dan tanpa ada beban dalam dirinya. ${ }^{22}$

Minat belajar peserta didik merupakan rasa suka dan ketertarikan kepada aktifitas belajar antara lain membaca,menulis, serta tugas praktek, tanpa ada yang menyuruh. Peserta didik yang memiliki minat belajar yang tinggi akan memperhatikan partisipasinya pada suatu aktivitas yang dia minati khusus di kelas.

Dari definisi yang ditentukan mengenai indikator minat belajar tersebut diatas, dalam penelitian ini menggnakan indikator minat yaitu :

a) Ketertarikan untuk belajar, keterlibatan siswa pada suatu obyek yang akan mengakibatkan orang tersebut senang dan tertarik untuk melakukan atau mengerjakan kegitan dari obyek tersebut. Aktif dalam diskusi, aktif bertanya, dan aktif manjawab pertanyaan dari guru.

b) Perhatian dalam belajar, Minat dan perhatian merupakan dua hal yang dianggap sama dalam penggunaan sehari-hari, perhatian siswa merupakan konsentrasi siswa terhadap pengamatan dan pengertian, dengan mengesampingkan yang lain. Siswa memiliki minat pada obyek tertentu maka dengan sendirinya akang memperhatikan obyek tersebut. Contoh : mendengarkan penjelasan guru dan mencatat materi. ${ }^{23}$

c) Motivasi belajar

Motivasi belajar dari perbuatan yang menuntut semangat dan kesungguhan, maka pembimbing harus senantiasa menjelaskan manfaat dan kegunaan belajar yang sedang mereka lakukan, tanpa pengertian dan pemahaman yang lengkap, maka motivasi yang murni tidak akan ada dalam diri si pelajar. ${ }^{24}$

d) Pengetahuan

Pengetahuan adalah informasi yang telah diproses dan diorganisasikan untuk memperoleh pemahaman, pembelajaran dan pengalaman yang terakumulasi sehingga bisa diaplikasikan ke dalam masalah/proses bisnis tertentu.

Lalu Pengertian Ilmu Pengetahuan Secara umum adalah suatu sistem berbagai pengetahuan yang didapatkan dari hasil pemeriksaan-pemeriksaan yang dilakukan secara teliti dengan menggunakan metode-metode tertentu. Secara etimologi, ilmu berasal dari bahasa arab dari kata ilm yang berarti memahami, mengerti, atau mengetahuai. Jadi dapat artikan bahwa ilmu pengethuan adalah memahami suatu pengetahuan. ${ }^{25}$

\section{METODOLOGI}

Jenis penelitian yang akan digunakan dalam penelitian ini, ialah penelitian kuantitatif lapangan (field research). Peneitian kuantitatif adalah penelitian yang

22 Siti Nurhasanah, A. Sobandi," minat belajar sebagai determinan hasil belajar siswa", Jurnal pendidikan manajemen perkantoran,1:1,(bandung,agustus 2016),h.137, diakses 29-09-2018

${ }^{23}$ Slameto, belajar dan faktor-faktor yang mempengaruhinya, ( jakarta : rineka cipta, 2010), h. 180.

24 Mustaqim, psikologi pendidikan, (yogyakarta,FAKULTAS TARBIYAH IAIN SEMARANG,2008),H.99

${ }_{25}$ http://umum-pengertian.blogspot.com/2016/01/pengertian-ilmu-pengetahuan-secaraumum.html.diambil pada hari senin 27-01-2019 
berlandaskan pada filsafat positivisme, yang digunakan untuk meneliti pada populasi atau sampel tertentu, teknik pengambilan sampel pada umumnya dilakukan secara random, pengumpulan data menggunakan instrument penelitian, analisis data bersifat kuantitatif/statistic dengan tujuan untuk menguji hipotesis yang telah ditetapkan. ${ }^{26}$

Sedangkan penelitian lapangan adalah penelitian yang menggunakan kehidupan nyata sebagai tempat kajian. Sehingga penelitian kuantitatif lapangan adalah penelitian yang dilakukan secara real pada kehidupan nyata yang menjadi konsentrasi dalam kajian yang diteliti dengan menggunakan tahapan-tahapan ilmiah yang bersifat analisis stistika berbasis angka-angka.

Adapun populasi dalam penelitian ini, guru dan seluruh siswa di SMP Negeri 11 Gorontalo siswa dari kelas VII sampai kelas IX yang berjumlah 320 siswa dan guru berjumlah 32 orang. Tehnik sampel yang yang digunakan dalam penelitian ini yaitu sampel jenuh dan stratified random sampling.

Di mana sampling jenuh ini sendiri adalah tehnik penentuan sampel bila anggota populasi digunakan sebagai sampel. Hal seperti ini sering dilakukan jika jumlah populasi relatif kecil. sampling jenuh itu sendiri digunakan untuk variabel $\mathrm{X}$ yang akan disebarkan pernyataan di 32 guru di SMP Negeri 11 Gorontalo ${ }^{27}$

Sedangkan untuk stratified random sampling tehnik ini peneliti gunakan bila populasi mempunyai anggota atau unsur yang tidak homogen dan berstrata secara profesional. ${ }^{28}$ Sampling ini sendiri peneliti gunakan untuk penyebaran angket pernyataan untuk siswa dengan jumlah populasi 320.

Karena keterbatasan peneliti yang disebabkan tersedianya waktu, dana,dan tenaga yang terbatas maka peneliti membatasi jumlah subjek penelitian yang diambil untuk dijadikan sampel, sehingga menggunakan sebagian dari populasi.

Menurut Suharsimi Arikunto ada beberapa rumus yang dapat digunakan oleh peneliti untuk menentukan jumlah anggota sampel. Jika peneliti mempunyai beberapa ratus subjek dalam populasi, maka peneliti dapat menentukan kurang lebih 25\%-30\% dari jumlah subjek tersebut. ${ }^{29}$

Adapun untuk menentukan ukuran sampel dari jumah populasi 320 siswa peneliti menggunakan $25 \%$ dari 320 populasi yaitu 80 reponden. Peneliti menggunakan tehnik stratified random sampling untuk variabel Y. Jadi untuk menentukan jumlah sampel di setiap kelas. ,kelas VII $=84$, VIII $=129$, dan kelas IX $=107$. Peneliti menggunkan perhitungan sebagai berikut:

$$
\begin{array}{ll}
\text { VII }=84 / 320 X & 80=21 \\
\text { VIII }=129 / 320 X & 80=32.25 \\
\text { IX }=107 / 320 X & 80=26.75 \text { dibulatkan } 27 \\
\hline \text { JUMLAH } & =80
\end{array}
$$

\footnotetext{
${ }^{26}$ Sugiono, metode penelitian endidikan : pendekatan kuantitatif, kualitatif, dan $R \& D$, (cet,XXII,Bandung : Alpabeta: 2015), h. 14.

${ }^{27}$ Sugiyono, Metode Penelitian Manajemen: Pendekatan kuantitatif, Kualitatif, dan R\&D, Cet. III Bandung: Al-Fabeta: 2014, h.156

${ }^{28}$ Sugiyono, Metode Penelitian Pendidikan: Pendekatan kuantitatif, Kualitatif, dan R\&D, Cet. III Bandung: Al-Fabeta: 2014, h. 152.

${ }^{29}$ Suharsimi Arikunto, Manajemen Penelitian,(jakarta :Rineka Cipta,2009)h.95
} 
Jadi jumlah sampel yang diambil di kelas VII $=21$ responden, $\mathrm{VII}=32$, dan kelas IX $=27 .{ }^{30}$

Tehnik pengumpulan data yang digunakan dalam penelitian ini adalah menggunakan kuesioner dan dokumentasi.

Analisis data merupakan kegiatan setelah data dari seluruh responden atau sumber data lain terkumpul. Kegiatan dalam analisis data ialah: mengelompokkan data berdasarkan variabel dan jenis responden, mentabulasi data berdasarkan variabel dari seluruh responden, menyajikan data dari setiap variabel yang diteliti, melakukan perhitungan untuk menjawab rumusan masalah, dan melakukan perhitungan untuk menguji hipotesis yang telah diajukan. ${ }^{31}$ Sesuai dengan jenis penelitan yang yang diangkat oleh peneliti dalam penelitian ini ialah jenis penelitian kuantitatif, maka proses analisis hipotesis untuk melihat pengaruh kompetensi pedagogik guru terhadap minat belajar siswa di SMP Negeri 11 kota Gorontalo. dilakukan dengan menggunakan analisa Regresi Sederhana dengan persamaan sebagai berikut:

Keterangan :

$$
\hat{\mathrm{Y}}=\mathrm{a}+\mathrm{bX}
$$

$\hat{\mathrm{Y}}=$ Nilai yang di prediksikan

$\mathrm{a}=$ Konstanta atau bila harga $\mathrm{X}=0$

$\mathrm{b}=$ Koefisien regresi

$\mathrm{X}=$ Nilai variabel independen.

Selain mengunakan persamaaan diatas dalam melakukan analisis data dalam penelitian ini, peneliti juga mengunakan Uji $t(t$ hitung $)$ untuk menguji signifikansi dari pengaruh yang ditimbulkan oleh variabel $\mathrm{X}$ terhadap variabel $\mathrm{Y}$, dengan rumus :

$$
\begin{aligned}
\mathrm{T}_{\text {hitung }} & =\frac{r \sqrt{n}-2}{\sqrt{1}-r^{2}} \\
\text { Dimana }: \mathrm{T}_{\text {hitung }}= & \text { Nilai } \mathrm{t} \\
\mathrm{r} & =\text { Nilai koefisien Korelasi } \\
\mathrm{n} & =\text { Jumlah sampel }
\end{aligned}
$$

Teknik analisis data dalam penelitian ini selain mengunakan analisa regresi linear sederhana peneliti juga mengunakan bantuan aplikasi SPSS versi 16.0.

\section{DESKRIPSI UJI VALIDITAS DAN REABILITAS}

\section{a. Uji validitas}

Sebelum peneliti turun penelitian di SMP Negeri 11 Gorontalo, sebelum itu peneliti turun mengujicobakan instrument di MTs Negeri 1 Bone Bolango adapun hasil dari uji coba instrument tersebut dari 30 item pernyataan tersebut didapatkan 27 item pernyataan yang valid. Maka dapat disimplkan bahwa untuk 27 item tersebut akan digunakan pada penelitian variabel X (Kompetensi Pegagogik guru )

Dari perhitungan uji validasi terhadap variabel $X$ (Kompetensi Pedagogik Guru) 27 butir item pernyataan dengan menggunakan taraf nyata $\alpha=0.05, \mathrm{~N}=32$ serta dengan

${ }^{30}$ Sugiyono, Metode Penelitian Manajemen: Pendekatan kuantitatif, Kualitatif, dan R\&D, Cet. III Bandung: Al-Fabeta: 2014, h.164

${ }^{31}$ Sugiyono, Metode Penelitian Manajemen, Cet. I, Bandung: Alfabeta, 2013, hal. 238. 
kriteria interval kepercayaan 95\%. Dan didapatkan hanya 27 item yang valid dikarenakan $r_{\text {hitung }}$ lebih besar dari $r_{\text {tabel. }}$.

Berdasarkan hasil uji coba di MTs Negeri 1 Bone Bolango dari 30 item pernyataan didapatkan hanya 27 item yang valid dikarenakan $r_{\text {hitung }}$ lebih besar dari $r_{\text {tabel. }}$. Maka dapat disimpilkan bahwa 27 item tersebut akan digunakan sebagai instrumen penelitian variabel Y.

Dari perhitungan uji validasi terhadap variabel $\mathrm{Y} 27$ butir item pernyataan dengan menggunakan taraf nyata $\alpha=0.05, \mathrm{~N}=80$ serta dengan kriteria interval kepercayaan $95 \%$.

Berdasarkan hasil uji coba instrumen penelitian diperoleh 27 item pernyataan valid, Hal ini dikarenakan $r_{\text {hitung }}$ dari semua pernyataan di atas lebih besar dari $r_{\text {tabel. }}$ Berdasarkan hal tersebut, maka dapat disimpulkan bahwa 27 item pernyataan yang terdapat pada angket dapat digunakan sebagai instrumen penelitian terhadap kompetensi pedagogik guru dan minat belajar siswa.

\section{b. Uji reliabilitas}

Berdasarkan hasil perhitungan uji reliabilitas di peroleh nilai $r$ sebagai berikut

\section{Hasil uji reliabilitas Variabel (X) kompetensi pedagogik}

Reliability Statistics

\begin{tabular}{|r|r|}
\hline $\begin{array}{c}\text { Cronbach's } \\
\text { Alpha }\end{array}$ & N of Items \\
\hline .752 & 28 \\
\hline
\end{tabular}

Merujuk dari hasil table out put tentang reliability statistics didapat koefisien alpha cronbach untuk variabel X (kompetensi pedagogik guru) yaitu sebesar 0.752. Jadi setelah uji instrumen ini sudah valid dan reliabel semua item pernyataanya, maka istrumen ini dapat dikatakan reliabel karena menunjukkan $0.751>0.6$.

\section{Hasil uji reliabilitas Variabel (Y) Minat Belajar Siswa Reliability Statistics}

\begin{tabular}{|r|r|}
\hline $\begin{array}{c}\text { Cronbach's } \\
\text { Alpha }\end{array}$ & N of Items \\
\hline .749 & 28 \\
\hline
\end{tabular}

Merujuk dari hasil table out put tentang reliability statistics didapat koefisien alpha cronbach untuk variabel Y (Minat Belajar Siswa) yaitu sebesar 0.749. Hasil ini menunjukkan bahwa instrument tersebut reliable karena $0.749>0.6 .{ }^{32}$

\section{c. Uji normalitas}

Hasil uji normalitas data Variabel X dan Y. Tests of Normality

\footnotetext{
${ }^{32}$ Sugiono Metode Penelitian Manajemen ( Bandung: Alfabeta , 2013)h. 220
} 


\begin{tabular}{|l|r|r|r|r|r|r|}
\hline & \multicolumn{3}{|c|}{ Kolmogorov-Smirnov $^{\mathrm{a}}$} & \multicolumn{3}{c|}{ Shapiro-Wilk } \\
\cline { 2 - 7 } & Statistic & \multicolumn{1}{c|}{ Df } & \multicolumn{1}{c|}{ Sig. } & Statistic & \multicolumn{1}{c|}{ Df } & \multicolumn{1}{c|}{ Sig. } \\
\hline Kompetensi & .137 & 32 & .135 & .936 & 32 & .057 \\
pedagogik & .130 & 32 & .183 & .949 & 32 & .137 \\
Minat belajar & & & & & 32 & \\
\hline
\end{tabular}

a. Lilliefors Significance Correction

Metode pengambilan keputusan untuk uji normalitas yaitu jika singnifikasi > 0.05 maka data berdistribusi normal dan jika signifikasi $<0.05$ maka data tidak berdistribusi normal. Pada hasil uji normalitas diatas, data Varibel X ( kompetensi pedagogik guru) nilai signifikasinaya sebesar 0.135 dan begitu pula pada Variabel Y (Minat Belajar Siswa) mempunyai nilai signifikasi sebesar 0.183. jadi karena nilai signifikasi dari kedua variabel diatas lebih dari 0.05 jadi dapat dinyatakan bahwa data tesebut berdistribusi normal.

\section{d. Uji korelasi}

Untuk mengetahui hubungan anatara variabel (X) kompetensi pedagogik guru) dengan Minat belajar sisiwa $(\mathrm{Y})$ dapat dilihat pada tabel sebagai berikut :

\section{Data hasil uji korelasi variabel $X$ dan $Y$}

\section{Correlations}

\begin{tabular}{|ll|r|r|}
\hline & & Minat belajar & Kompetensi pedagogik \\
\hline $\begin{array}{l}\text { Pearson } \\
\text { Correlation }\end{array}$ & $\begin{array}{l}\text { Minat belajar } \\
\text { Kompetensi } \\
\text { pedagogik }\end{array}$ & 1.000 & .586 \\
\hline Sig. (1-tailed) & $\begin{array}{l}\text { Minat belajar } \\
\text { Kompetensi } \\
\text { pedagogik }\end{array}$ & .586 & 1.000 \\
\hline $\mathrm{N}$ & $\begin{array}{l}\text { Minat belajar } \\
\text { Kompetensi } \\
\text { pedagogik }\end{array}$ & 32 & .000 \\
\hline
\end{tabular}

Berdasarkan tabel corelations di atas, bahwa besarnya hubungan antara Variabel X (Kompetensi Pedagogik Guru ) dengan Variabel Y (Minat Belajar Siswa ) yang dihitung dengan koefisien korelasi adalah 0.586. Berdasarkan hasil perhitungan tersebut menunjukan adanya hubungan yang Cukup Kuat antara Kompetensi Pedagogik Guru dengan Minat Belajar Siswa di SMP Negeri 11 Gorontalo. Untuk memberikan interfrestasi koefisien korelasi maka digunakan digunakan pedoman interprestasi koefisien korelasi sebagai berikut : 
Pedoman untuk memberikan interprestasi koefisien korelasi

\begin{tabular}{|c|c|}
\hline Interval Koefisien & Tingkat Hubungan \\
\hline $0,00-0,199$ & Sangat Rendah \\
\hline $0,20-0,399$ & Rendah \\
\hline $\mathbf{0 , 4 0 - 0 , 5 9 9}$ & Cukup Kuat \\
\hline $0,60-0,799$ & Kuat \\
\hline $0,80-0,1000$ & Sangat Kuat \\
\hline
\end{tabular}

e. Uji regresi sederhana

Data hasil regresi sederhana

Coefficients $^{\mathrm{a}}$

\begin{tabular}{|c|c|c|c|c|c|}
\hline \multirow[b]{2}{*}{ Model } & \multicolumn{2}{|c|}{$\begin{array}{l}\text { Unstandardized } \\
\text { Coefficients }\end{array}$} & $\begin{array}{l}\text { Standardized } \\
\text { Coefficients }\end{array}$ & \multirow[b]{2}{*}{$\mathrm{t}$} & \multirow[b]{2}{*}{ Sig. } \\
\hline & B & $\begin{array}{l}\text { Std. } \\
\text { Error }\end{array}$ & Beta & & \\
\hline 1(Constant) & 20.450 & 21.661 & & .944 & .353 \\
\hline $\begin{array}{l}\text { Kompetensi } \\
\text { pedagogik }\end{array}$ & .710 & .179 & .586 & 3.959 & \\
\hline
\end{tabular}

a. Dependent Variable:

Minat belajar

Berdasarkan tabel coefficients diatas dapat di gambarkan bahwa persamaan regresi dalam penelitian ini, yakni sebagai berikut : $\mathrm{Y}=\mathrm{a}+\mathrm{b}_{\mathrm{x}}=20.450+0.710 \mathrm{x}$. konstanta sebesar 20.450 menyatakan jika tidak ada kenaikan nilai dari Variabel X, maka maka nilai Variabel Y adalah 20.450. koefisien regresi sebesar 0.710 menyatakan bahwa setiap penambahan 1 (satu) nilai variabel $\mathrm{X}$ akan Memberikan peningkatan nilai Variabel Y sebesar 0.710 .

Pada tabel ANOVA yang didapatkan melalui uji regresi sederhana melalui program SPSS 16.0 terdapat kolom untuk nilai $\mathrm{F}$ berarti jika kita juga harus mencari terdahulu nilai $\mathrm{F}_{\text {tabel }}$ nya sehingga analisis ini akan menjadi lebih mudah menggunakan nilai sig. Kriteria yang digunakan dalam pengujian ini ialah jika nilai signifikasi lebih dari atau sama dengan nilai alfha $(\alpha)$ yang telah ditentukan, maka $\mathrm{H}_{\mathrm{O}}$ diterima yang artinya persamaan garis regresi tidak linear dan jika nilai Sig. kurang dari nilai alpha maka $\mathrm{H}_{\mathrm{O}}$ ditolak yang artinya persamaan garis regresi linear.

ANOVA $^{\mathrm{b}}$

\begin{tabular}{|ll|r|r|r|c|c|}
\hline Model & & Sum of Squares & df & Mean Square & F & Sig. \\
\hline 1 & Regression & 1145.572 & 1 & 1145.572 & 15.675 & .000 \\
& Residual & 2192.428 & 30 & 73.081 & & \\
& Total & 3338.000 & 31 & & & \\
\hline
\end{tabular}

a. Predictors: (Constant), Kompetensi pedagogik 
ANOVA $^{\text {b }}$

\begin{tabular}{|ll|r|r|r|r|r|}
\hline Model & & Sum of Squares & df & Mean Square & F & Sig. \\
\hline 1 & Regression & 1145.572 & 1 & 1145.572 & 15.675 & .000 \\
& Residual & 2192.428 & 30 & 73.081 & & \\
& Total & 3338.000 & 31 & & & \\
\hline
\end{tabular}

b. Dependent Variable: Minat belajar

Pada tabel ANOVA yang telah diperoeh dengan menggunakan SPSS 16.0 dapat dilihat nilai signifikasi sebesar 0.000 nilai signifikasi ini lebih kecil dari nilai $\alpha$ yaitu 0.05 artinya bahwa kita menolak $\mathrm{H}_{\mathrm{O}}$ berarti bahwa ada persamaan garis regresinya linear. Berdasarkan tabel ANOVA ataw uji $\mathrm{F}$, ternyata didapat $\mathrm{F}_{\text {hitung }}$ adalah 15.675 dengan tingkat signinifikan 0.000 atau 0 . Karena probabilitas (0.000) jauh lebih kecil dari 0.05, sehingga model regresi dapat dipakai untuk memprediksi variabel Y.

Sedangkan untuk melihat seberapa besar konstribusi variabel independent yaitu variabel X (Kompetensi Pedagogik Guru ) terhadap variabel dependent yaitu variabel $\mathrm{Y}$ ( Minat Belajar Siswa) dengan melihat nilai $\mathrm{R}$ - Square pada tabel berikut ini :

Model Summary

\begin{tabular}{|l|r|r|r|r|}
\hline Model & $\mathrm{R}$ & \multicolumn{1}{|c|}{ R Square } & \multicolumn{1}{c|}{$\begin{array}{c}\text { Adjusted R } \\
\text { Square }\end{array}$} & $\begin{array}{l}\text { Std. Error of the } \\
\text { Estimate }\end{array}$ \\
\hline 1 & $.586^{\mathrm{a}}$ & .343 & .321 & 8.549 \\
\hline
\end{tabular}

a. Predictors: (Constant), Kompetensi pedagogik

Pada tabel diatas dapat dilihat nilai R-squarenya adalah 0.343 yang berarti bahwa pengaruh variabel $\mathrm{X}$ (Kompetensi pedagogik guru ) terhadap variabel $\mathrm{Y}$ (minat belajar siswa) sebesar $34.3 \%$ pengarunya, dan $65.7 \%$ adalah pengaruh dari variabel lainya yang tidak di tetili oleh peneliti.

\section{f. Uji t}

Berdasarkan tabel coefficient di atas, pada kolom unstandardized Coefficient, nilai $X$ (kompetensi pedagogik guru ) sebesar 0.710 dan nilai $t_{\text {hitungna }}$ nya sebesar 3.959. dengan derajat kebebasan $=\mathrm{n}-2=32-2=30$ dan $\alpha=0.05$, sehingga di peroleh nilai $t_{\text {tabel }}=0.349$. sehingga nilai $t_{\text {hitug }}>t_{\text {tabel }}$ atau $3.959>0.361$, maka $H_{O}$ ditolak dan $\mathrm{H}_{\mathrm{a}}$ diterima, yang berarti koefisien regresi berpengaruh secara signifikan. Dengan demikian terbukti berdasarkan Uji t bahwa kompetensi pedagogik guru (X) berpengaruh terhadap Minat Belajar Siswa (Y) di SMP Negeri 11 Gorontalo. 


\section{KESIMPULAN}

Berdasarkan hasil penelitian yang telah di bahas pada bab sebelumnya dan untuk menjawab rumusan masaalah pada penelitian ini,maka akhir dari skripsi dapat ditarik kesimpulan sebagai berikut :

1. Terdapat pengaruh fositif kompetensi pedagogik guru terhadap minat belajar siswa dengan persamaan regresi $\mathrm{Y}=20.450+0.710 \mathrm{x}$. di mana signifikanya berpengaruh tersebut ditunjukan oleh nilai $t_{\text {hitung }}$ (uji $t$ ) di mana $t_{\text {hitung }}>t_{\text {tabel }}$ yaitu $3.959>0.361$ dengan nilai signifikansi $<0.05$ yaitu 0.000 dengan sumbangan relatif sebesar 100\% dan sumbangan efektif $34.3 \%$.

2. Melalui analisis regresi sederhana pada tabel $\mathrm{R}$ Square, diketahui Pengaruh variabel $\mathrm{X}$ (Kompetensi pedagogik guru) terhadap variabel $\mathrm{Y}$ (minat belajar siswa) di SMP Negeri 11 Gorontalo sebesar 34.3\%, hal ini berarti $65.7 \%$ minat belajar siswa dipengaruhi oleh faktor yang lain.

\section{REFERENSI}

Ahmad Rasuli,Wanto Rivaie,Sulistyarini",kompetensi guru dalam meningkatkan hasil belajar siswa mata pelajaran sosiologi," (jurnal, prodi pendidikan sosiologi,pendidikan IPS,FKIP Untan Pontianak 2012)

Daryanto, Guru Profesional ,(Yogyakarta: Gava Media, 2013)

E. Mulyasa, standar kompetensi dan sertifikasi guru (cet. VI: jakarta, remaja rosdakarya,2012)

Erwinsyah, Alfian. "Penerapan Pembelajaran Berbasis Teknologi Informasi Dalam Menunjang Kinerja Guru." Prosiding Seminar Nasional Administrasi Pendidikan \& Manajemen Pendidikan. 2018.

Imas kurnianigsih dan berlin sani, kupas tuntas kopetensi pedagogik teori dan praktik,(kata pena; 2017)

Jamil Suprihatinigrum, Guru Profesional:pedoman Kinerja, Kualifikasi Dan Kompetensi Guru, (jogjakarta: Ar-Ruzz media,2013)

Lukmanul hakiim, perencanaan pembelajaran, (bandung:cv wacana prima 2012)

Rahman Getteng, Menuju Guru Profesional dan ber-etika,( Cet. VI, Yogjakarta: Grha Guru,2011)

Undang-Undang Republik Indonesia Nomor 20 Tahun 2003 Tentang SISDIKNAS, (Bandung:Fermana, 2006)

Sadulloh uyoh, pedagogik, ilmu mendidik (bandung : alfabet. Rosda karya 2001).

Zainal Aqib, Menjadi Guru Profesional Berstandar Nasional. (Bandung: Yarma Widya,2009)

Arif Firdausi, Barnaw I, Profil Guru SMK Profesinal , (jogjakarta : ar-ruzz, media 2012)

Fitri Indriani, Kompetensi Pedagogik Guru Dalam Mengelola Pembelajaran Ipa Di Sd

Dan Mi, jurnal fenomena, 1:7,(yogjakarta,2015),h.19, diakses 29-09-2018

Jamil Suprihatinigrum, Guru Profesional:pedoman Kinerja, Kualifikasi Dan Kompetensi Guru, (jogjakarta: Ar-Ruzz media,2013)

Siti Asiah T. Pido, Kinerja Guru Tersertifikasi,(Gorontalo: Sultan Amai Press, 2015)

Rulam ahmadi, Profesi keguruan,(Jogjakarta: Ar Ruzz Media, 2 018),h.23 
Slameto, belajar dan faktor-faktor yang mempengaruhinya, ( jakarta : rineka cipta, 2010) Mustaqim, psikologi pendidikan, (yogyakarta,Fakultas Tarbiyah Iain Semarang,2008)

Sidik, Firman. "Guru Berkualitas Untuk Sumber Daya Manusia Berkualitas." Tadbir: Jurnal Manajemen Pendidikan Islam 4.2 (2016): 109-114.

Sugiono, metode penelitian endidikan : pendekatan kuantitatif, kualitatif, dan $R \& D$, (cet,XXII,Bandung : Alpabeta: 2015)

Sugiyono, Metode Penelitian Manajemen: Pendekatan kuantitatif, Kualitatif, dan R\&D, Cet. III Bandung: Al-Fabeta: 2014

Suharsimi Arikunto, Manajemen Penelitian,(Jakarta :Rineka Cipta,2009) 